\title{
Dissemination of Demographic and Socio-Economic Developments in Tirana with Special Attention to Youth Education
}

\author{
Prof. Dr. Bukuri Dumani ${ }^{1}$ \\ Dr. Ruzhdie Bici ${ }^{2}$ \\ Prof. As. Dr. Nexhmi Dumani ${ }^{3}$ \\ Msc. Blerina Subashi ${ }^{2}$ \\ Msc. Alma Kondi ${ }^{2}$ \\ ${ }^{1}$ Department of Statistics, University of Tirana, Albania \\ ${ }^{2}$ Institute of Statistics, Tirana, Albania \\ ${ }^{3}$ Mediterranean University of Albania, Albania
}

Doi: 10.2478/jesr-2018-0020

Abstract

Tirana, the capital of Albania, has a population of 420,000 inhabitants, with a surface area of $40 \mathrm{~km}^{2}$ and a population density of 10.5 thousand inhabitants. From the territorial point of view of the organization , Tirana has 11 administrative units. Half of the population in Tirana is less than 35 years old and half, more than 35 years old. Tirana has the highest level of socio-economic developments in the country and most of the domestic migrants who after the change of economic systems in 1990, are located in Tirana. The article analyzes the level of demographic and socio-economic developments in Tirana according to its 11 administrative units, their inequalities and similarities, with particular attention to the education of young people, the enrollment of students in secondary school after completing nine year basic education. Although Tirana has the highest socio-economic development in the country, its administrative units have quite different levels of development. The net enrollment rate at secondary school for students who have completed nine years of basic education and enroll in the secondary is low; (only $67 \%$ of students) compared with net enrollment rate at secondary school in EU countries over 85\%). A student in Tirana who has a difficult economic situation, parents with low education level, school far away, the absence of one or both parents in the family, many household members, is much more likely not to enroll in secondary school, after completing basic obligatory education, nine years education. Economic and social developments in Tirana highlight a development of Tirana with many profiles. From the 11 administrative units in five-of them, the developments are relatively lower than in the other six administrative units. The less developed administrative units in Tirana are: the 6th and 11th units and the highest developments administrative unites are the 10th and 5th units. In Unit 6, one in seven people are poor although in Unit 10 one in 25 people are poor. To improve the development, it should be implemented concrete programs and projects with territorial approaches; Education has an essential role to play out of poverty and change the quality of life. This role should be empowered by the state and families by becoming more and more vulnerable to the ideology of education and the quality of education. There are used data from Census 2011 and Living Standard Measurement Survey, LSMS 2012. Descriptive, factorial, cluster analysis and regression methods were used for the analysis of sociodemographic and economic developments. For data processing were used Spss, Stata and Matlab.

Keywords: Economic and social development, education demand and supply, risk factors 


\section{Introduction}

Tirana is the city with the largest population in the country. The establishment of Tirana as an urban center dates from 1614 (Jasa, 1997). On February 11, 1920, Tirana became Albania's capital city. Following the proclamation, the capital adds administrative, economic, social and cultural functions, taking the appearance of an urban capital (Miho, 2003). In the first general population Census in Albania in 1923, Tirana counted 10.8 thousand inhabitants (Instat, 2013). In 1945, Tirana had about 60,000 inhabitants. Before the collapse of the communist regime in the 1989 Census, Tirana had 238 thousand inhabitants. In the 2001 Census, its population grew sensitive also due to internal migration, which was previously rigorously controlled. Based on 2011 Census, in Tirana there are 419 thousand inhabitants. The population of Tirana accounts for almost one-third of the population of cities or $15 \%$ of the population of Albania. Tirana's prefecture based on 2011 Census had 750 thousand or almost $1 / 3$ of Albania's population.

In Tirana nearly one in ten people is poor. Meanwhile, a 21-years-old person in Tirana has completed an average of 12 years of schooling and nearly one-third of the 21-years-olds have at least one university degree, comparable figure with countries in the region and beyond. After system changed, in 1990, Albania inherited an educational level with significant achievements in relation to economic developments. In the early 1990s, Albania, according to the Human Development Index (HDI), was ranked 10 times higher than the GDP per capita (UNDP, 1995), and in 2014, Albania HDI is ranked 14 countries ahead of GNI (UNDP, 2015) which shows the important social achievement, such as education and life expectancy, rather than economic developments. According to HDI, Albania is ranked in the 85th place from 188 countries around the world.

Despite the country's limited economic and financial resources, a low productivity of the economy, education has been consistently considered a priority in development policies, a tool of individual and social emancipation.

Following thelaw passed by the state in -1946 for the elimination of illiteracy for $12-40$ years old and gender inequalities in education, in 1952, was introduced compulsory seven-year education for children ages $7-14$. In 1965, from the seven-year system were moved into the compulsory eightyear system. Since 2004-2005, the nine-year education system becomes compulsory from 6 to 16 years old. Actually, the structure of pre-university education was organized: 5 years of elementary education, 4 years of lower secondary education and 3 years of general secondary education (not included the professional education level). In the early 1990s, despite the public schools, the first private schools were visible; and private education expands more and more. Although educational achievements in Tirana are important compared to economic developments, net enrollment of upper secondary school students is still low; only $67 \%$ of students aged $15-18$ old who have completed compulsory education (nine years) enroll in secondary school, while in Europe and other countries in the region this figure is more than $85 \%$. For Albania, only $62 \%$ of students aged $15-18$ old are enrolled in the upper secondary school. Despite the profound changes in the education system, educational attainment and attendance rates are quite different from one region to another in Albania (Bici, Dumani, 2016) and between administrative units in Tirana.

Socio-economic and demographic developments in Tirana vary greatly from one administrative unit to another. There is a characteristic relationship of different variables with the same influenced direction visible to all 11 units. There is no administrative unit where there is evidence of lower education, lower unemployment, lower poverty, and higher per capita consumption.

\section{Data and Methodology}

Data are obtained from the 2011 Census and the Living Standard Measurement Survey 2012. The 2011 Census data analyzes the distribution of developments in Tirana by administrative units. There are taken in the consideration ten variables with demographic, economic and social dimensions. Data analysis has been used for key component methods, factor analysis, cluster analysis and logistic regression. The 2012 Living Standard Measurement Survey data analyzes the enrollment in the secondary school of students aged 15-18 who have completed nine years of 
school. Five explanatory variables for enrolling or not enrolling in secondary school students are reviewed. Regression analysis was used to test the regressive relationship between enrollment and other influenced variables. LSMS is much power full and it takes to the consideration multidimensional factors influencing the education, while the Census can be produce data in lower administrative divisions, $11^{\text {th }}$ units in our case. LSMS 2012 allows estimating different socioeconomic development indicators on the urban and rural level, regions and prefecture of Albania (World Bank, Instat, 2016).

Results are produced using different statistical programs like SPSS, Stata, Matlab.

\section{Demographic and Socio-Economic Development of Tirana}

\subsection{Demographic profile}

Tirana is divided into 11 administrative units (Figure 1$)^{1}$. The population in each administrative unit varies from 15 thousand inhabitants up to 10 thousands inhabitants, and in some administrative unit. in two of them the number is over 60 thousand inhabitants

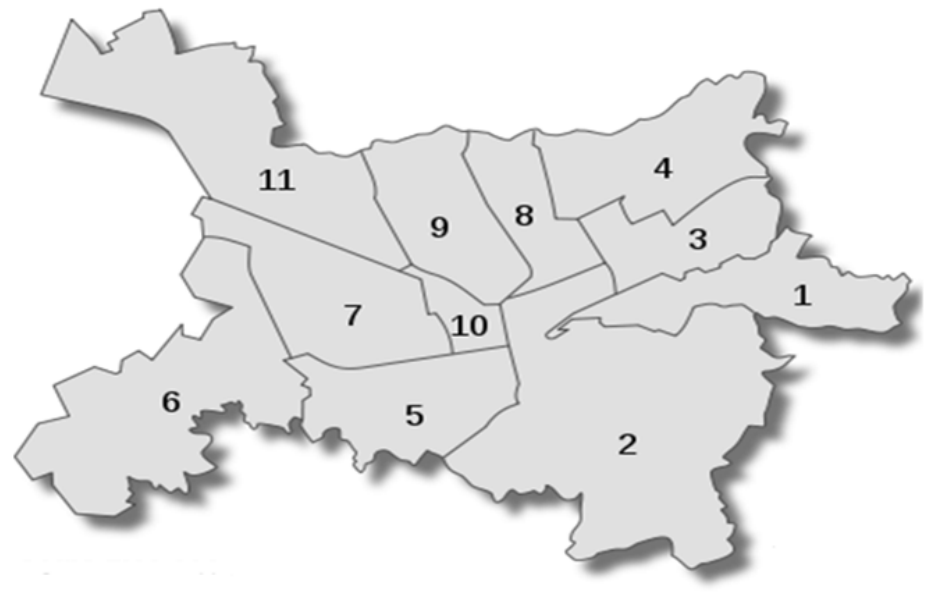

Figure 1. Administrative units of Tirana

The density of Tirana is 10.5 thousand inhabitants per $\mathrm{km}^{2}$ or 2-3 times more than the majority of the capitals of the Europe ${ }^{2}$. The City center, administrative unit 10 have the highest population density, more than 20 thousand inhabitants per $\mathrm{km}^{2}$, followed by unit 5 and 9 . The units with lower population density are the units that are located more in the periphery of Tirana, units $1,2,6,11$ (Annex 1).

Although Tirana is getting older faster than the rest of the country, its age structure is still relatively young (Figure 2). Average age in Tirana was 36.2 in 2011 from 33.4 in 2001 and 30.1 in 1989 (median age of the population of Tirana is about 34 years old from 42.2 years (January 1 , 2014) to EU28 countries ${ }^{3}$.

\footnotetext{
1 www.reformaterritoriale.al/kryesore/ligji-115-2014. "Për ndarjen administrativo territoriale të njësive të qeverisjes vendore në Republikën e Shqipërisë"

${ }^{2}$ http://www.citymayors.com/statistics/largest-cities-density-125.html; The largest cities in the world and their mayors 2010. (For countries with higher population density, 40 first places belong to developing countries).

${ }^{3}$ Ec.europa.eu/statistics/population
} 


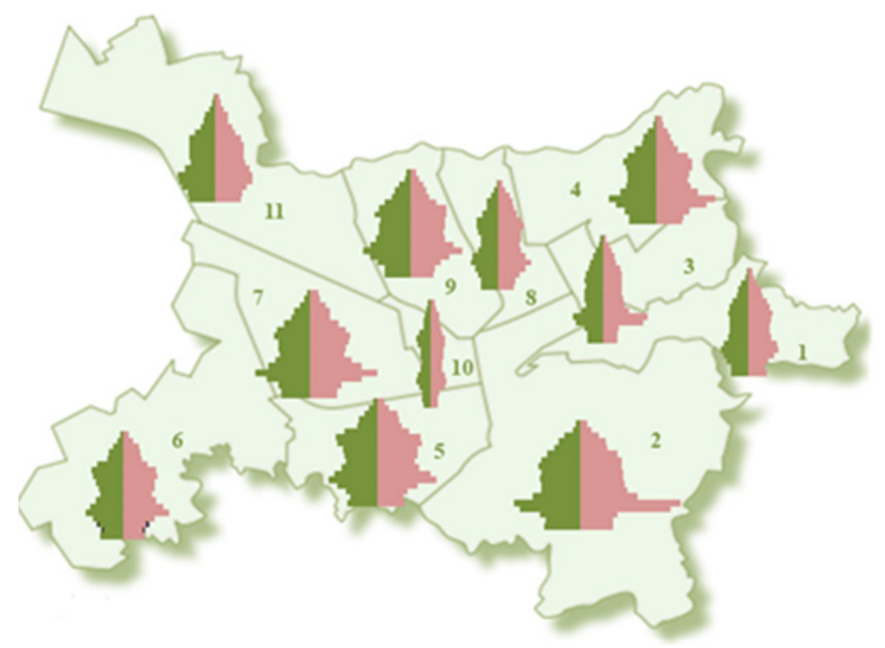

Figure 2. Age structure of the population of Tirana, Census 2011

In all administrative units it is noticed that the narrowing of the pyramid base, the continuing decline in fertility and the increase in the average age of the population. The lowest average age is in Units 11 and 6 , respectively 33.4 and 34.8 years. The highest average age is in the $10^{\text {th }}$ and $5^{\text {th }}$ units, respectively 41.4 years and 38.2 years old. In Units 6 and 11 there are more children $0-14$ years (about 21\%). Also, the youth dependency coefficient is higher in the $6^{\text {th }}$ and $11^{\text {th }}$ Units. The most noticeable breakdown of the age pyramid of the population in Unit 2, so visible from the others, is explained by the presence of the most numerous students in this unit.

\subsection{Consumption, poverty and inequality}

The analysis of developments in Tirana points out a characteristic association of indicators from one unit to another. Where schooling is higher, per capita consumption is higher, education is higher, lower poverty and unemployment is lower, (Annex 2, 3).

Poverty, depth and severity of poverty are higher in the $6^{\text {th }}$ and $11^{\text {th }}$ Units. Actually (April 2017) in Tirana there are 2287 families in economic assistance and $18 \%$ reside in the $6^{\text {th }}$ administrative Unit. In Tirana, inequality in consumption is higher than inequality in education. The Gini consumption coefficient is 0.27 and for years of education for the population 21 years and above reaches 0.18 , which expresses the commitment of families and individuals to education even when economic resources are limited. Inequality in consumption is lower in $6^{\text {th }}$ and $11^{\text {th }}$ Units; In these units, citizens are more unequal in consumption than in education.

\subsection{Employment and unemployment}

The structure of employment has been changed with years (Instat, 2017). Using the employment data collection source is not possible to produce data by administrative units. So in these conditions we will judge for the development trend till that year and the variables taken together configuration the simultaneous socio-economic development for Tirana and its administrative units.

In Units 1, 3, 4, 6, 11, unemployment is above the average level of unemployment in Tirana; about one-third of the labor force in these units was unemployed, from $22.5 \%$ to Tirana. Unlike the $10^{\text {th }}$ unit where unemployment is twice as low and poverty is nearly 4 times lower than in units 6 and 11. The unemployment rate according to the Census 2011 in Tirana was $22.5 \%$. In 2015 unemployment reached 17\% (Instat, 2015) and in 2016 about 14\% (Instat, 2016).

Unemployment among young people is higher. The highest levels for men and women are in 
the age group $20-29$ year old, especially in the age group 20-24 (Figure 3). Unemployment in 2011 is more widespread in all ages compared to 2001 (Dumani, Koka, 2008). Activity coefficients are lower for both men and women in 2011.
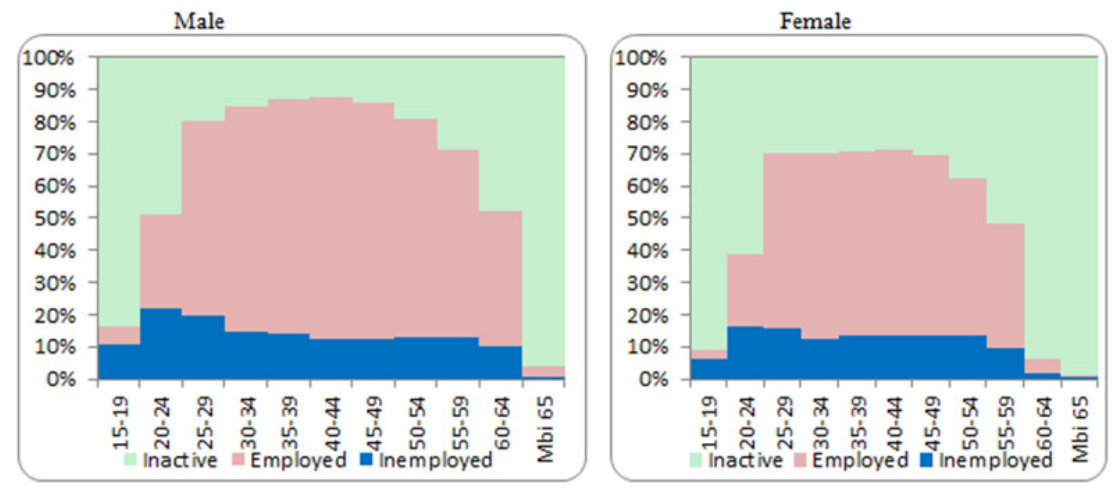

Figure 3. Employment and Unemployment in Tirana, Census 2011

Labour force participation rate coefficients are higher in males than females; the highest levels of economic activity coefficient for males are reached in the age group 30-49 and for women in the age group $25-49$ years old.

\subsection{Educational achievement}

Educational achievement expresses the process of human capital formation through completion various levels of schooling.

Educational achievements of Albania compared to EU countries for the 25-64 age population have quite a difference ${ }^{4}$; in Albania, nearly $1 / 2$ of $25-64$ year olds have only a nine-year diploma, or twice as high as in the EU21 and OECD countries. The share of the population with secondary education in Albania is also much lower. Meanwhile, the percentage of adults with higher education is twice as low in Albania than in EU21 countries (Table 1).

Table 1. Educational achievement for the population 25 - 64 years by diploma level, 2014

\begin{tabular}{|c|c|c|c|c|c|}
\hline & \multicolumn{4}{|c|}{ Education achievement \% } & \multirow[b]{2}{*}{ Total } \\
\hline & Till primary & $\begin{array}{l}8 / 9 \text { years of school } \\
\text { (lower secondary) }\end{array}$ & $\begin{array}{l}\text { Upper } \\
\text { secondary }\end{array}$ & $\begin{array}{l}\text { University } \\
\text { or higher }\end{array}$ & \\
\hline Albania & 8 & 42 & 35 & 15 & 100 \\
\hline EU21 & 7 & 14 & 47 & 32 & 100 \\
\hline OECD & 8 & 15 & 44 & 33 & 100 \\
\hline
\end{tabular}

Source: OECD. Stat Database (online education); For Albania: LSMS 2012

Average number of schooling for the population 25 years old and over is 10.1 years based on LSMS 2012 (Annex 2, 3). This level is increased but still is far compared with other regional countries like Croatia, Montenegro, Serbia, Rumania, Slovenia where the average years of schooling are around 11-12 years and other developed European countries where the mean years

\footnotetext{
${ }^{4}$ Is considered age group 25-64 years old for comparison purpose with European Countries
} 
of schooling varies from 11 to 14 years per person aged 25 and over ${ }^{5}$.

The highest years of schooling for the population 25 years and over for 2012 have England, 13.8 years, Switzerland, 13.8 years and German 13.3 years. The increase of years of schooling by areas based on LSMS 2012 have changed with faster rhythm compared with earlier periods (Figure 4).

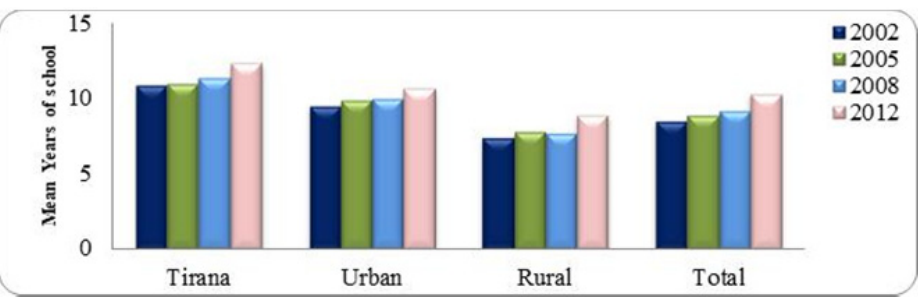

Figure 4. Average number of schooling for the population aged 21 years and higher Source: LSMS 2002, 2005, 2008, 2012

The average number of years of schooling has increased from one survey to another for the country and each area. Tirana is the most educated area. A person aged 21 and over in Tirana has averaged 12.1 years of school ${ }^{6}$.

After changing the system in 1990, internal movements were free; internal migrants are mostly concentrated in Tirana. Those arriving in Tirana after 1991 have influenced the increase of the average number of years of education for the citizens of Tirana. Migrants who continue to come to live in Tirana have spent more years in school, compared to the non-migrant population.

Migrants from rural areas toward urban centers often have a higher educational level than the rest who do not migrate, as they have more knowledge about the opportunities for a better life that an urban center or capital has to offer (Dumani, 1997). Compared to non-migrant people in the city are often less educated paradoxically, departures from these areas can cause a decrease in the average level of education both in the destination and in the places of origin. But in the case of Tirana the arrivals (migrants) have contribute to increase of average years of school of the population of Tirana. In the case of the non-migrant population in Tirana, a person aged 21 years and above had completed an average of 11.4 years of schooling, the arrivals in Tirana after 1991 had averaged 11.7 years of schooling and arrived population after 2001 have completed on average 12.4 years of schooling.

In the city of Tirana one in three 21 years old and over has a university degree or higher (Instat, 2012), almost the same level as the EU and OECD countries in 2014. The situation by administrative units in Tirana is very different. It seems unbelievable, but data from the 2011 Census show that in the $5^{\text {th }}$ and $10^{\text {th }}$ Administrative units in Tirana one in two persons aged 21 and older have at least a university degree. Percentage of university degree up to 21 years old and over in 2011 varies from $13 \%$ to $49 \%$. The lowest percentage of persons 21 years and older with at least a university degree is at $6^{\text {th }}$ and $11^{\text {th }}$ unit respectively $13 \%$ and $20 \%$ respectively, $33 \%$ for Tirana.

In units with higher levels of development in the $10^{\text {th }}$ and $5^{\text {th }}$ units, unemployment is at a lower rate, but the unemployed is visible even for people with higher education; in unit 10 , about $40 \%$ of the unemployed are under higher education and in unit 5 it reaches $35 \%$. In other units, the share of the unemployed with higher education (to total unemployed of each unit) ranges from $18-24 \%$.

The question arises: is market inefficiency, or high completed diplomas, some of them, are inefficient, or both? In order to be responsive, market research, job-seeking proposals should be undertaken, stimulation of the debate on the quality of education and possession of knowledge versus getting diploma.

Studies for the labour market demand-supply almost non-existent and not rare diploma reduced to the instrumental dimensions. For years, the issue of a more appropriate educational and

\footnotetext{
${ }^{5}$ ec.europa.eu/eurostat/data/database

${ }^{6}$ Lsms database: http://www.instat.gov.al/en/figures/micro-data.aspx
} 
learning curriculum offering has been raised in line with market demands. Although there is a late shift to change, there is still a disadvantage in Albania among students enrolled in vocational secondary education and general secondary education, which reaches $13 \%$ in vocational education and $87 \%$ in general secondary education. In many European countries this ratio for students enrolled in vocational secondary education varies from $33 \%$ to $84 \%{ }^{7}$. These strong differences, recommend a deep reform in the educational offer.

For persons 21 years of age and higher with university degree and above, the level of poverty is higher compared to persons with secondary vocational education. The poverty level for persons 21 years and over with $4 / 5$ year secondary vocational education is 3 times lower than those with gymnasium, respectively $3 \%$ by $9 \%$.

Albania's population is $82.6 \%$ (Instat, 2012) and is composed of population with ethnic and cultural backgrounds in Albania, and $17.4 \%$ consists of Greek, Macedonian, Montenegrin, Romanian, Roma, Egyptian and Greek ethnicities. For the educational achievement, the Roma population presents a profound contrast: a person aged 15 years and over or 21 years and above has averaged 3.1 years of school, compared with 12 years of schooling for Tirana and about 10 years for Albania.

This state of affairs in the Roma community constitutes accusation of the system and appeal for quick changes. Moreover, when talking about Albania's EU integration, the ethnic dimension of poverty is at the center of the credentials of the association of new countries.

But just comparing school years and supposing all the other equal would not help change the situation without concrete children's education programs in this community. The education of Roma children is not merely a matter of bringing an ethnic group and "supposing all the other equal". The real world is made up of the difference "all unequal things collected" (Nurja, Sevrani and Dumani, 2014) and standardization should not make the gross results forget. Thus, "the school performance of Roma children is lower, but with a comparable mother's degree the difference fades". Thus, children of Roma origin do not go in school (all the other equal things): their mothers are on average less graduate than mothers of other children, which means they are less familiar with the school universe and that teachers should treat the differences realistically amongst students as well because these differences do not come directly from ethnicity of origin.

In the Roma community, mothers with higher levels of education also have children with a higher educational achievement (Figure 5).

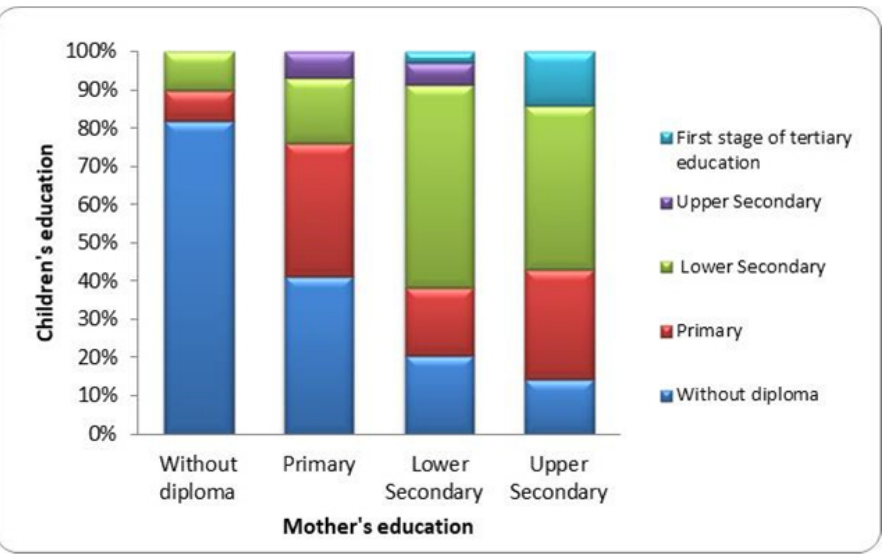

Figure 5. Education of individuals aged 21 years old and over by education of mother to Roma community

Source: INSTAT, Census 2011

\footnotetext{
${ }^{7}$ data.uis.unesco.org/Index.aspx?datasetCode=EDULIT_DS
} 
In mothers with no diploma to the Roma ethnicity, $80 \%$ of children are without a degree, while with the growth of mother's education, the percentage of Roma children without school or a primary school diploma drops from one level to another. In mothers with a secondary school diploma, only $10 \%$ of children 21 years and older are without school or without a degree in elementary school; while $60 \%$ of children have at least a nine year school diploma.

\section{Students enroll in secondary education}

\subsection{Participation in secondary education}

Participation in education shows the current registration of different ages in school activity. Unlike the educational achievement that points to those who have completed a certain level, participatory indicators are indicative of the moment.

The net enrollment in basic education from 7 to 15 years of age is almost complete (Bici, Dumani, 2016). The age of 15 years corresponds to the end of the nine-year primary school education for the earliest pupils. The registration begins to decrease at the age of 15 and older at the age of 16 . While in Albania the decline starts immediately after $8 / 9$ years of education, in OECD countries the high fall in enrollment rates (World Bank, Instat 2016) is observed at the end of secondary school. The net enrollment of students in secondary school is quite low, only $62.4 \%$ of over $85 \%$ in Europe. Some countries have even higher enrollment rates in the middle, such as Slovenia 93\%, Israel 92\%, Japan $97 \%$, etc. The net enrollment of students in secondary school in Tirana is low, 67\%, the same as the net enrollment rate in LSMS 2008 (Bici, Dumani, 2016). Low enrollment in secondary education faces supply and demand issues.

\subsection{Reasons for Not Enrolling at Secondary School}

There are declared three main reasons for non-enrollment in secondary school that make up about $80 \%$ of the cases:

a. Almost half consider their completed education with the achieving nine year basic education. b. They have no interest in pursuing further. c. The school costs too much (Figure 6).

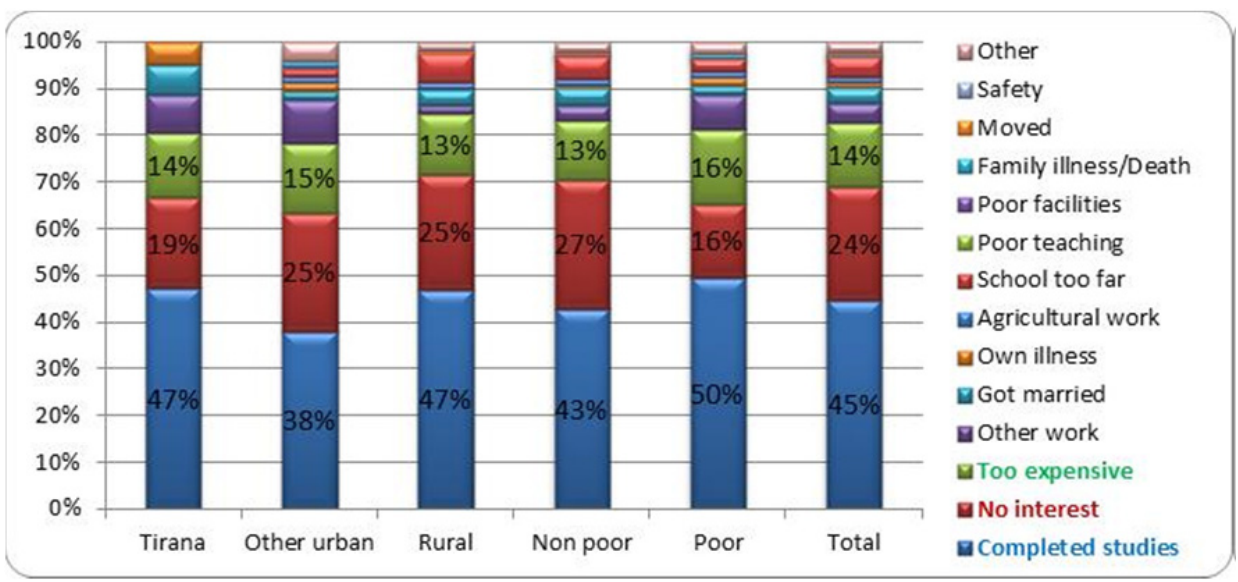

Figure 6. Reasons for Not Enrolling in Secondary School

Source: Lsms 2012, (author's calculation)

Schooling costs are sensitive to families in economic difficulties. An assessment shows that in Tirana nearly 5,500 children aged $15-18$ year olds live in economically poor households (LSMS 2012). But is poverty affecting the level of schooling or non-attendance is influencing poverty? 
In poor families, the life of children is difficult; children live with adult concerns to ensure basic condition for living. And when children are concerned about survival conditions, it's not easy for them to focus on school culture. In a difficult financial situation or deteriorating families will spend on education only if survival is safe (Pair, 2000). But people do not choose to live in misery.

Empirical analyzes show the complexity of the links between poverty and education, as well as their evolutionary character; research does not establish systematic correspondence between the poverty level and the costs that households spend on child education (Henaff, et al. 2009). If education can play a role in the fight against poverty, the nature and importance of this role remains controversial (Henaff, et al. 2009).

Although poverty may be an easy obstacle to overcoming, family poverty is not enough to explain student non-enrollment; other factors not only economical factors can affect to reduce it, such as engaging parents more effectively in the ideology of schooling. The school also has an important compensating role in the face of forms of poverty and that it should constantly convey the message that education should be developed regardless of poverty, in order to enable the emergence of poverty (Henaff, et al. 2009). The school does not recognize parents difficulties in raising and educating children in poor families. Faced with forms of poverty, often geographically focused, the role of the school is significant (Fougère, 2007).

When the majority of unregistered students consider completed studies of nine years of education, they have no interest in continuing school, feel insecure in the labor market, etc., state, school education efforts, and co-ordination with family endeavors remain opportunities for boosting demand for more education.

School education is largely determined by educational offerings (Henaff, et al. 2009). Educational offer should awaken interest that the diploma of secondary education be evaluated in the labor market, not diploma for diploma, instrument diploma. Having a diploma does not always prove successful if the graduates do not possess the knowledge and do not respond to the market.

When parents are more educated, poverty is at lower levels, families have more commodities including more books, and children are prone to performance better than those in poor families (Henaff, et al. 2009).

Data on Albania shows that with the increase of parents' education, the poverty of children and young people decreases. The poverty rate for children aged 15-18 with parents up to 8/9 years of age is over twice as high as that of secondary education (Table 2).

Table 2. Poverty level and net enrollment rate to the secondary education by education of the mother in Albania

\begin{tabular}{lccc}
\hline Education of the mother & \multicolumn{2}{c}{ Poverty level of children and youth, \% } & Net enrollment rate for \\
& $0-18$ age old & $15-18$ age old & $15-18$ age old \\
Nono & 30.1 & 29.3 & 48.9 \\
Basic & 23.3 & 20.4 & 55.6 \\
Secondary & 18.0 & 12.1 & 71.6 \\
University and higher & 6.9 & 4.6 & 71.0 \\
Total & 19.7 & 16.2 & 62.4 \\
\hline
\end{tabular}

Souces: Lsms 2012 (authors calculation)

The household poverty level is not enough to explain non registration of the students. This means that even to the non poor households exist non registration, leading effect of other factors. In the poor household, $37 \%$ of the children aged $15-18$ years old who have completed 9 years of school or the basic education are not registered to the secondary level. In the non poor households $32 \%$ of the children who have finished the basic education level are not registered to the secondary (Annex 4). 


\subsection{Determinants of (non) enrollment in secondary schools}

To analyze the links and the importance of variables in secondary school enrollment, an analysis was carried out on the basis of the logistic regression model. The data used belong to children 1518 years old who have completed 8/9 year school. Dependent variable is categorical with two levels, whether or not enrolled in secondary school. The following explanatory variables were found to be most appropriate:

- Poverty status (Poverty)

- Maternal Education (Education)

- Distance of school (Distance)

- Number of children under 15 years old in the household (Children)

- Child with and without parents (Parent)

Two models were implemented $(\mathrm{A}, \mathrm{B})$. The results show that the explanatory variables included in the models $A, B$ carry the explanatory power $(p \leq 0.01)$, affecting the expected link direction and the coefficients are at 95\% confidence intervals (Annex 5).

Secondary school enrollment is adversely affected when a student lives in a poorer family with lower parent education when the school is away (more than 30 minutes) when there are more children in the family than the age of work when a student lacks one or both parents in the family. In model A where the economic variable (poor /non poor) is included, its importance in non-enrollment in secondary school is indicated. A poor student has 1.3 times higher chance of enrolling in secondary school than a poor one, when other variables in the model remain constant.

Model B includes variables: poverty, school distance, maternal education, the number of children out of working age, and the presence of a parent in the family. The results shows that all variables in the model are significant and in the expected direction of the links.

Family poverty is not enough to explain the non-enrollment of students. In poor families, $37 \%$ of 15-18 year olds who are under nine are not enrolled in the middle. In non-poor households, $32 \%$ of children who are under nine are not enrolled in the middle (Annex 4).

Children with 8/9 year-old motherhood are less likely to be over 1.6 times more than enrolled in secondary school compared to children whose mothers have completed high school and upper secondary school.

In families with one and two children 15 years or less, the chances of enrollment in the middle are respectively 6 times and 3.5 times higher than in families with three or more children.

The absence of one or both parents in the family is a risk factor for enrolling high school students. A single-parent or parent-parent student has the risk of not registering more than 3 times higher than the children with both parents. The risk of a parent's absence in secondary school enrollment is much higher in Tirana than in Albania, over 3 times and 1.2 times higher than children with both parents.

A student who has a school over 30 minutes walking away from home has 1.3 times higher risk of not enrolling in high school compared to the student who has the nearest school. The same explanations for Tirana have also proved important for Albania and its region (Bici, Dumani, 2016).

\section{5. (No) Development System}

Sectorial analysis stops at the special treatment of each development indicator and is supportive of integrated analysis, but they lack the wider context, the summary context of developments. Integrating city problems into a multi-dimensional analysis encourages positive changes by giving the system more development capacity. Through factorial analysis many variables information can be summed up in few factors. To the factorial analyses were considered ten variables for three dimensions of development: demographic, economic and social as follows:

\section{Demographic dimensions}

The average number of members in the family

The ratio of youth dependence 


\section{Economic size}

Average consumption per inhabitant

Unemployment

Poverty level

The severity of poverty

Number of residents per room

\section{Social Dimensions}

Average years of schooling for 21 year olds and over

Percentage of persons 21 years old and over with a university degree and upwards Inequality in Education

Correlative correlations of variables included in a factor analysis initiate model performance as the correlation matrix contains high correlations and partial correlations of low (Annex 6).

The factor analysis model performs perfectly: Information from 10 variables is summarized in a single factor $(94.13 \%$ of variance of 10 components, value of statistic $\mathrm{KMO}=0.77, \mathrm{p}<.0001)$.

The latent structure expresses a general trend with the same development direction in the administrative units. The ranking of the Tirana administrative units according to the factor of economic and social development evidences the $6^{\text {th }}$ and $10^{\text {th }}$ administrative units at the end of developments in Tirana: lower developments in unit 6 and higher in unit 10 (Figure 7).

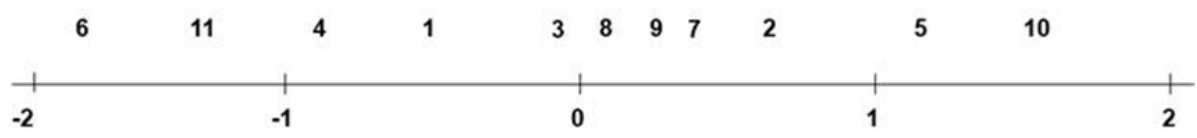

Figure 7. Ranking of Tirana Administrative Units by factor of economic and social development

The $6^{\text {th }}$ and $11^{\text {th }}$ units on one side of the axis and the $5^{\text {th }}$ and $10^{\text {th }}$ units on the other hand differ greatly from other Units: $6^{\text {th }}$ and $11^{\text {th }}$ units are less developed in the whole of developments reviewed in the model; The opposite is found in the $5^{\text {th }}$ and $10^{\text {th }}$ units.

Factors of the factor are arbitrary and aim to identify a relative confrontation of administrative units with fewer and higher developments (Figure 8). The figure shows that the administrative units with relatively lower development are: $6,11,4,1,3$. Meanwhile, the units with relatively higher developments are: 10, 5, 2, 7, 9 and 8 .

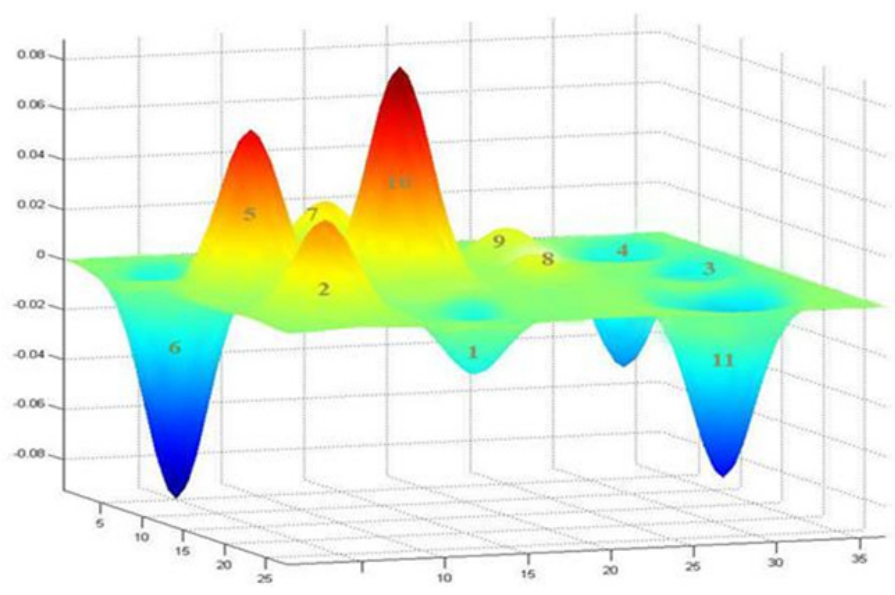

Figure 8. Socio-demographic development of administrative units in Tirana by main factors, Census 2011 
The assessment of demographic- and social- economic developments by administrative units (proportional look) points to Tirana "with many Tirana" (Figure 9). Despite improvements in some variables in Tirana and its administrative units, unit positions between two censuses ${ }^{8}(2001,2011)$ are similar $(\mathrm{Rs}=0.952)$.

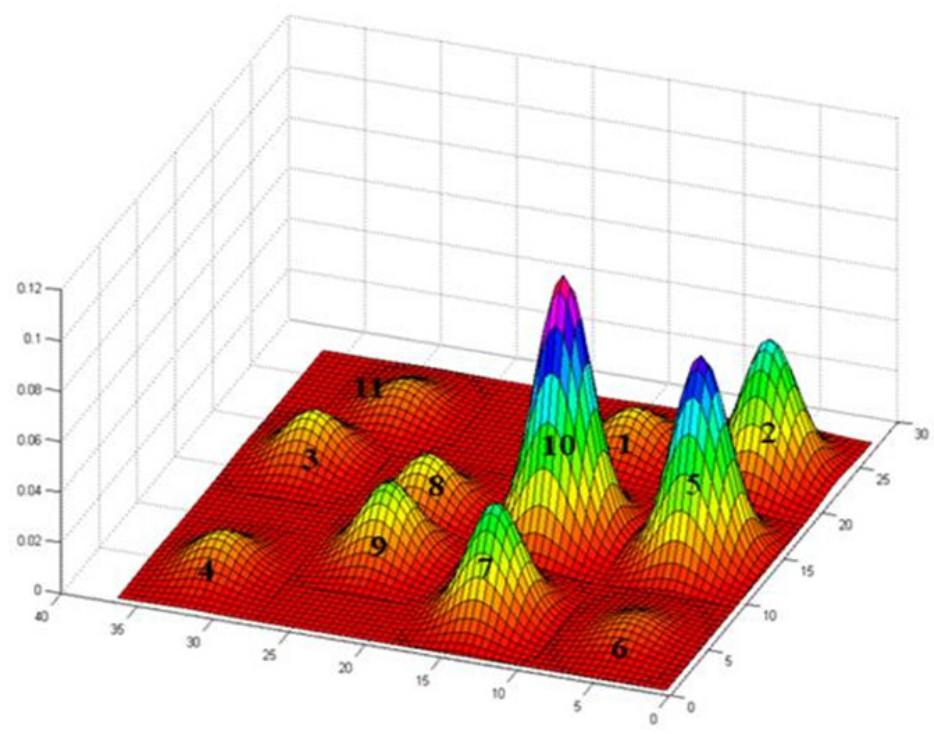

Figure 9. Evaluation of economic and social developments in the Tirana administrative units, Census 2011

By comparing estimates for the social and economic development of Tirana with Census data $2001^{9}$ and 2011 it is noticed that the administrative units 1, 6, 7, 8 have been downgraded; units 2 , $3,9,11$ have been improved, a place has been added to the rankings, and units $4,5,10$ have not changed the rankings. In 2001, the $7^{\text {th }}$ ranked third, in 2011 , is 2 nd in third place after $10^{\text {th }}$ and $5^{\text {th }}$ in $10^{\text {th }}$ place $^{10}$. The ranking of the administrative units and their grouping on the basis of economic and social developments show significant variability of development.

Cluster analysis allows the division of data, such as variables and subjects into homogeneous subgroups. Cluster analysis is an exploration procedure that often helps to understand the complex nature of links between variables. When data is grouped, some distance distances are used as a proximity index.

The clustering of administrative units and their cluster analysis is as follows (Figure 10):

In the first group: A 5, 10

In the second group: $2,7,8,9$

In the third group: $1,3,4$

In the fourth group: A 6, 11

\footnotetext{
${ }^{8}$ Tirana Reliev demo-ekonomik e social. 2005. Ilar, f. 107

${ }^{9}$ Tirana Reliev demo-ekonomik e social. 2005. Ilar, f. 107

${ }^{10}$ Purpose of this comparison is to give a total configuration of development despite any restriction for the lack of any variable for two years.
} 


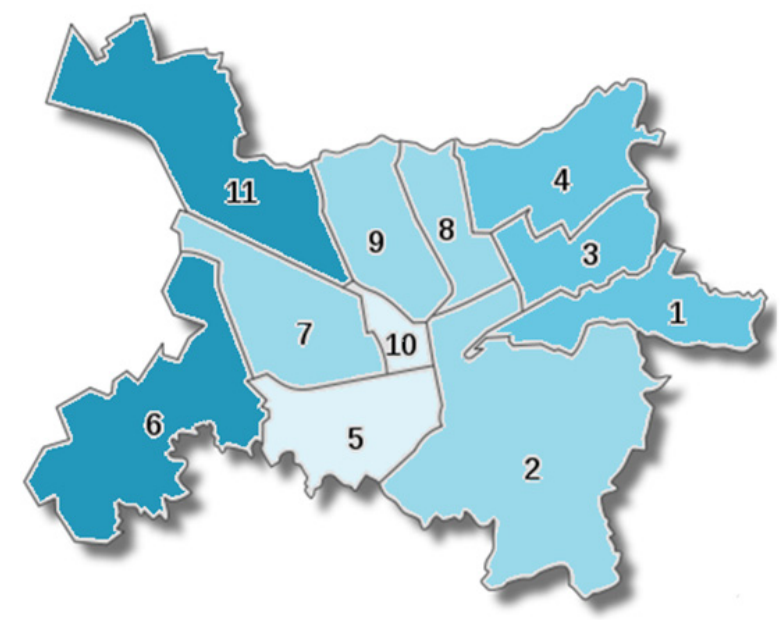

Figure 10. Grouping of Administrative Units according to Social Economic Development of Tirana, Census 2011

Territorial neighbors seem to be just as neighbors and in the whole of economic and social development. This grouping can create chances for effective intervention by the Municipality of Tirana such as lowering non-variable costs at group-level, potential investment at a time or chain in certain groups. With the city as a system, it is possible to efficiently scale the scale of the problematic sectors. From this point of view, pressure is placed on creativity and initiative, which become a factor of progress and that more decision-making centers will function more actively.

\section{Conclusions and Recommendations}

\subsection{Conclusions}

The demographic- and socio- economic developments in Tirana highlight a multifaceted Tirana. There is a characteristic association of developments where information from all variables is summarized in a single factor.

Less developed units are the $6^{\text {th }}$ and $11^{\text {th }}$ units and with relatively higher development are the $10^{\text {th }}$ and $5^{\text {th }}$ units. In units 6 and 11 there are more members per household or larger household size, more children and elderly dependents, more unemployment, more poverty, more extreme poverty, more people in one room, less per capita consumption and more little inequality in consumption, less education, more inequality in education than other units.

The secondary school enrollment analysis highlights the importance of parents' education, poverty, household size, lack of parenthood, distance to school, in Tirana. (The same variables are important determinants both at country and region level (Bici, Dumani, 2016).

\subsection{Recommendations}

Tirana needs to tackle faster, more swift changes to distribute progress anywhere, especially in units $6\left(11^{\text {th }}\right.$ Combination) (Lapraka), where the percentage of children is higher.

When it comes to the education of children, policies must be concrete, especially for students with economic difficulties, for students living in families with poor economic conditions. It is necessary to develop concrete programs and projects with territorial approaches; social targeting of education policies for children in poor families, for children with 1 parent or no parents (such as free vocational training, etc.) and employment opportunities in poor families.

Education of students to the Secondary and university level is a matter of demand and 
educational supply. Educational offer should awaken interest that the diploma of secondary and higher education be evaluated in the labor market. Encouraging the debate about the quality of education can increase the accountability of all that the diploma is not a diploma for a degree, an instrument diploma but reflects the mastery of knowledge. Action should be public; having a diploma does not always prove successful if the graduates do not possess the knowledge and do not respond to the market.

Educational institutions, parents, families, and society will need to be more involved in the ideology of child education. Better education, under other equal conditions, enables the preparation of employees capable of absorbing modern technology and accelerating innovation. "Let's change society to change school, change school to change society," writes French magazine Cahiers pedagogique since 2007. So much for Albania, Tirana and any territorial unit of this change of society from school, or school from society will need to be tackled quickly without wasting time.

\section{Reference}

Bici, R., Dumani, B. (2016). Factors influencing low net enrollment rate to secondary education, International Journal of Science Innovation and New Technology, Tirana.

Dumani, B., (1997), Elementë të demografisë, Popullsia dhe Zhvillimi, albin, fq 89.

Dumani, B., Koka. M. (2008), Zhvillimet në Tiranë, Refleksione mbi sfida, International Konference, Economic \& social challenges and problems, Universiteti i Tiranës Fakulteti i Ekonomisë,Tiranë;

Fougère, D., (2007). Grande pauvreté et politiques éducatives. L'actualité éducative du $\mathrm{N}^{\circ} 451$, [Online], www.cahiers Pedagogiques.com/Grande pauvreté et politiques éducatives.

Henaff, N., Lange, M. F., Martin, J. Y. (2009/1) ( $\left.n^{\circ} 3\right)$. Revisiter les relations entre pauvreté et éducation, Revue Française de Socio-Économie [online]; https://www.cairn.info/resume.php? ID_ARTICLE=RFSE_003.

Instat, (2012), Censusi i Popullsisë dhe banesave, 2011 Rezultate kryesore, Shtypshkronja "Adel Print", f. 71.

Instat, (2013), Censusi i Popullsise dhe banesave, Tirana 2011, Shtypshkronja "Adel Print", 2013, f. 84.

Instat, 2015, Tregu i punës në Shqipëri, f. 28;online:www.instat.gov.al.

Instat, 2016, Tregu i punës në Shqipëri, www.instat.gov.al.

Jasa, S., (1997), Tirana, Botues Victoria, , f. 23-75.

Miho, K., (2003), Shqipëria: vështrim urbanistik 1912-1944", Botues, Tirana: Extra, f. 238.

Nurja, I., Sevrani, K., Dumani, B., (2014), Education in Albania based on Living Standards Measurements Survey (LSMS), International Journal of Science, Innovation and Technology. Tiranë, 2014, pp 49-59.

Pair, C., (2000). L'école devant la grande pauvreté, Revue Quart Monde, N.174-Passion d'apprendre [online]. www.editionsquartmonde. $\mathrm{org} / \mathrm{rqm} /$ personne. $\mathrm{php}$ ?id=2158.

UNDP, (1995), report.hdr.undp.org, Human Development Report 1995, HDI ranking for industrial countrie, 1992, Oxford Unicersity Press, p. 18.

UNDP, (2015), report.hdr.undp.org, Human Development Report 2015, Statistical annex, pp 208-246

Wold Bank, Instat, (2016), Profili i varfërisë dhe i pabarazisë në Shqipëri, f. 1-3

ec.europa.eu/eurostat/data/database.

Lsms database: $\mathrm{http}: / /$ www.instat.gov.al/en/figures/micro-data.aspx.

www.reformaterritoriale.al/kryesore/ligji-115-2014. "Për ndarjen administrativo territoriale të njësive të qeverisjes vendore në Republikën e Shqipërisë". 


\section{ANNEX}

Annex 1. Population density in Tirana by administrative units

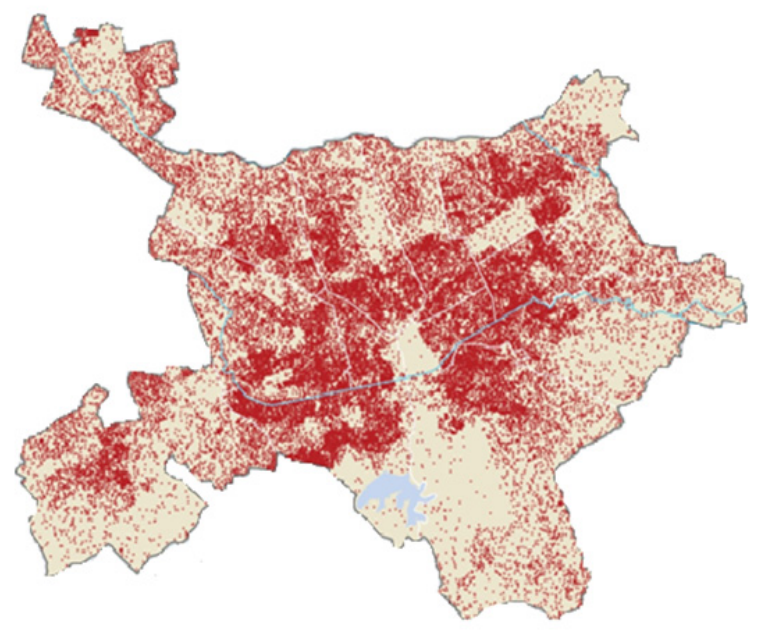

Source: Instat, Census 2011

Annex 2. Demo-economical and social development of Tirana by administrative unit

\begin{tabular}{c|c|c|c|c|c|c|c}
\hline $\begin{array}{c}\text { Administrati } \\
\text { unit }\end{array}$ & Population & $\begin{array}{c}\text { Density } \\
\text { per km2 }\end{array}$ & $\begin{array}{c}\text { Household } \\
\text { size }\end{array}$ & $\begin{array}{c}\text { Dependency } \\
\text { coefficient }\end{array}$ & $\begin{array}{c}\text { Dependency } \\
\text { coefficient of youth }\end{array}$ & $\begin{array}{c}\text { Persons } \\
\text { per room }\end{array}$ & $\begin{array}{c}\text { \%, Persons } 21 \text { years old and over with } \\
\text { university or higher + }\end{array}$ \\
\hline 1 & 27,032 & 7,100 & 3.7 & 0.410 & 0.247 & 1.4 & 0.25 \\
2 & 58,299 & 7,455 & 3.6 & 0.378 & 0.215 & 1.2 & 0.40 \\
3 & 31,440 & 14,627 & 3.5 & 0.385 & 0.223 & 1.4 & 0.29 \\
4 & 42,076 & 11,034 & 3.7 & 0.380 & 0.249 & 1.5 & 0.26 \\
5 & 46,776 & 16,059 & 3.2 & 0.387 & 0.210 & 1.2 & 0.49 \\
6 & 34,847 & 6,033 & 3.9 & 0.456 & 0.306 & 1.5 & 0.13 \\
7 & 51,288 & 14,803 & 3.4 & 0.375 & 0.220 & 1.3 & 0.38 \\
8 & 27,782 & 14,654 & 3.4 & 0.421 & 0.235 & 1.3 & 0.33 \\
9 & 41,323 & 15,208 & 3.5 & 0.383 & 0.226 & 1.3 & 0.36 \\
10 & 14,975 & 20,330 & 3.0 & 0.430 & 0.181 & 1.2 & 0.49 \\
11 & 42,657 & 8,875 & 3.9 & 0.430 & 0.306 & 1.5 & 0.20 \\
\hline Tirana & $\mathbf{4 1 8 , 4 9 5}$ & $\mathbf{1 0 , 4 7 3}$ & $\mathbf{3 . 5}$ & $\mathbf{0 . 3 9 8}$ & $\mathbf{0 . 2 3 9}$ & $\mathbf{1 . 3}$ & $\mathbf{0 . 3 3}$ \\
\hline
\end{tabular}

Annex 3. Demographic and socio-economic development of Tirana by administrative unit

\begin{tabular}{c|c|c|c|c|c|c|c|c}
\hline $\begin{array}{c}\text { Administrati } \\
\text { unit }\end{array}$ & $\begin{array}{c}\text { Year of schooling } \\
\text { 21 years old and } \\
\text { over }\end{array}$ & $\begin{array}{c}\text { Unemployment } \\
\text { coefficient }\end{array}$ & $\begin{array}{c}\text { Consumption } \\
\text { per capita }\end{array}$ & $\begin{array}{c}\text { Poverty } \\
\text { head-count }\end{array}$ & $\begin{array}{c}\text { Poverty } \\
\text { gap }\end{array}$ & $\begin{array}{c}\text { Poverty } \\
\text { severity }\end{array}$ & $\begin{array}{c}\text { Ginni of } \\
\text { consumption }\end{array}$ & $\begin{array}{c}\text { Ginni of shooling } \\
\text { of 21 years old } \\
\text { and over }\end{array}$ \\
\hline 1 & 11.8 & 0.254 & 9,977 & 0.104 & 0.019 & 0.005 & 0.269 & 0.180 \\
2 & 12.9 & 0.187 & 11,466 & 0.063 & 0.011 & 0.003 & 0.271 & 0.166 \\
3 & 12.0 & 0.245 & 10,593 & 0.085 & 0.015 & 0.004 & 0.268 & 0.176 \\
4 & 11.7 & 0.264 & 9,565 & 0.123 & 0.024 & 0.007 & 0.267 & 0.185 \\
5 & 13.5 & 0.163 & 12,032 & 0.057 & 0.010 & 0.003 & 0.272 & 0.161 \\
6 & 10.4 & 0.297 & 8,952 & 0.145 & 0.028 & 0.008 & 0.263 & 0.185 \\
7 & 12.8 & 0.198 & 10,778 & 0.082 & 0.014 & 0.004 & 0.273 & 0.167 \\
8 & 12.3 & 0.215 & 10,649 & 0.090 & 0.017 & 0.005 & 0.273 & 0.176 \\
9 & 12.6 & 0.221 & 10,727 & 0.081 & 0.014 & 0.004 & 0.270 & 0.174 \\
10 & 13.6 & 0.147 & 12,822 & 0.040 & 0.007 & 0.002 & 0.271 & 0.154 \\
11 & 11.1 & 0.292 & 9,452 & 0.125 & 0.023 & 0.007 & 0.267 & 0.190 \\
\hline Tirana & $\mathbf{1 2 . 3}$ & $\mathbf{0 . 2 2 5}$ & $\mathbf{1 0 , 5 9 9}$ & $\mathbf{0 . 0 8 9}$ & $\mathbf{0 . 0 1 6}$ & $\mathbf{0 . 0 0 5}$ & $\mathbf{0 . 2 7 1}$ & $\mathbf{0 . 1 7 9}$ \\
\hline
\end{tabular}


Annex 4. Percentage of students $15-18$ years old enrolled or not to the upper secondary by economic situation

\begin{tabular}{ccccc}
\hline & Not enroll, $\%$ & Enroll, $\%$ & Total, $\%$ \\
\hline Non poor & 32 & 68 & 100 \\
Poor & 37 & 63 & 100 \\
\hline Total & 33 & 67 & 100 \\
\hline
\end{tabular}

Annex 5. Dependent variable of enrollment of students to upper secondary, Tiranë, LSMS 2012

\begin{tabular}{|c|c|c|c|c|c|c|}
\hline \multirow{2}{*}{$\underline{\text { Variable }}$} & \multicolumn{3}{|c|}{ Model A } & \multicolumn{3}{|c|}{ Model B } \\
\hline & $\underline{\beta}$ & Odds ratio & $\underline{\text { Sig }}$ & $\underline{\beta}$ & Odds ratio & $\underline{\text { Sig }}$ \\
\hline Intercept & -0.102 & & 0.000 & -0.196 & & 0.000 \\
\hline \multicolumn{7}{|l|}{ Poverty } \\
\hline Non poor & 0.206 & 1.264 & 0.000 & 0.181 & 1.198 & 0.000 \\
\hline Poor & & & & & 1 & \\
\hline \multicolumn{7}{|l|}{ Distance } \\
\hline More than $30^{\prime}$ & & & & -0.294 & 0.745 & 0.000 \\
\hline Less than $30^{\prime}$ & & & & & 1 & \\
\hline \multicolumn{7}{|l|}{ Mother education } \\
\hline Without completed education & & & & (a) & & 0.000 \\
\hline Basic education & & & & -0.474 & 0.623 & 0.000 \\
\hline Secondary and higher & & & & & 1 & 0.000 \\
\hline \multicolumn{7}{|c|}{ Number of children less than 15 years old } \\
\hline One child & & & & 1.787 & 5.973 & 0.000 \\
\hline Two children & & & & 1.243 & 3.467 & 0.000 \\
\hline Three or more children & & & & & 1 & \\
\hline \multicolumn{7}{|l|}{ Parents in the household } \\
\hline None/with one parent & & & & -1.117 & 0.327 & 0.000 \\
\hline Both parents & & & & & 1 & \\
\hline
\end{tabular}

Annex 6. Table of the correlation between variables, Census 2011

\begin{tabular}{|c|c|c|c|c|c|c|c|c|c|c|c|}
\hline $\begin{array}{l}\frac{0}{0} \\
\frac{0}{0} \\
\frac{0}{\pi} \\
\frac{\pi}{7}\end{array}$ & 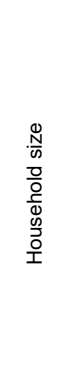 & 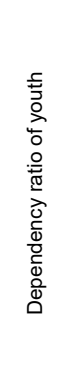 & 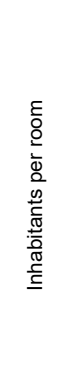 & 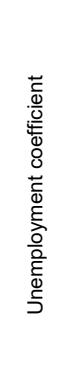 & 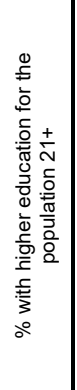 & 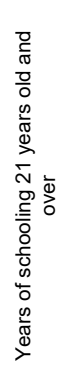 & $\begin{array}{l}\bar{\Phi} \\
\frac{\Phi}{\Phi} \\
\text { 离 } \\
\stackrel{0}{0}\end{array}$ & 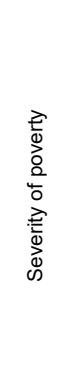 & 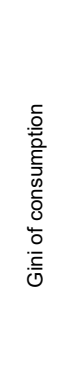 & 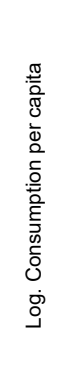 & 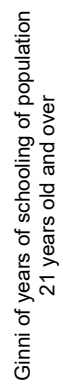 \\
\hline Household size & 1.000 & & & & & & & & & & \\
\hline Dependency ratio of youth & .896 & 1.000 & & & & & & & & & \\
\hline Inhabitants per room & .831 & .851 & 1.000 & & & & & & & & \\
\hline Unemployment coefficient & .918 & .917 & .962 & 1.000 & & & & & & & \\
\hline$\%$ with higher education for the population $21+$ & -.910 & -.913 & -.934 & -.983 & 1.000 & & & & & & \\
\hline Years of schooling 21 years old and over & -.908 & -.938 & -.930 & -.977 & .994 & 1.000 & & & & & \\
\hline Poverty level & .898 & .933 & 944 & .962 & -.962 & -.967 & 1.000 & & & & \\
\hline Severity of poverty & .864 & .932 & .925 & .927 & -.923 & -.940 & .987 & 1.000 & & & \\
\hline Gini of consumption & -.762 & -.763 & -.819 & -.819 & .819 & .849 & -.786 & -.771 & 1.000 & & \\
\hline Log. of consumption per capita & -.919 & -.915 & -.939 & -.975 & .970 & .963 & -.990 & -.960 & .758 & 1.000 & \\
\hline
\end{tabular}

